\title{
ORGANIZATIONAL JUSTICE AS AN ANTECEDENT OF JOB PERFORMANCE
}

\author{
AizzatMohd. Nasurdin \\ Soon Lay Khuan
}

The present research examines the influence of organizational justice (distributivejustice and procedural justice) on predictingjob performance (task performance and contextual performance). Survey data were drawn from a sample of 136 customer-contact employees within the telecommunications industry in Malaysia. Results of the regression analysis illustrate that distributive justice alone has a significant and positive relationship with task performance. On the other hand, only procedural justice is found to be significantly and positively related to contextual performance. Implications of the findings and directions for future research are highlighted.

Keywords: contextual performance; customer-contact employees; distributive justice; Malaysia; procedural justice; task performance 
Gadjah Mada International Journal of Business, September - December 2007, Vol. 9, No. 3

\section{Introduction}

In a competitive business environment, behavior of frontline employees play a critical role in ensuring the success of a service provider. Being in boundary-spanning occupations, these employees represent the key link between the external customer and the organization. For service-oriented companies, the effective performance of customer-contact workers would directly and significantly affect customers' perception of the level of service quality offered, thus creating a losing or winning ground for the related service providers in the market place. Customer-contact employees who perform tasks and activities efficiently which include keeping customers' records correctly and solving customers' queries promptly would provide a favorable impression on the service, thereby enhancing the image of the service provider. Similarly, by engaging in activities beyond their formal role prescriptions such as assisting their colleagues that are temporarily burdened with work, providing informal mentoring for lesser skilled staffs, and displaying acts of courtesy and goodwill to customers, customer-contact employees are bound to contribute to better service. According to Wang et al. (2003), superior service quality will have positive consequences in the form of enhanced reputation, higher customer satisfaction and retention, and greater profitability for the service organization.
Historically, Katz(1964) has identified two basic types of behaviors that are necessary for organizational effectiveness in the form of in-role and extra-role job behaviors. In-role behavior reflects predictable job performance responsibilities that must be carried out in order to implement the organization's essential operations. If employees fail to perform these required behaviors, they do not receive organizational rewards and they may lose their jobs. These types of behaviors are synonymous with task performance (Borman and Motowidlo 1997) or in-role behaviors (Bott et al. 2003; Williams and Anderson 1991). On the other hand, extra-role behavior reflects variable patterns of behaviors that fall outside of one's job descriptions yet facilitate the accomplishments of organizational goals (Katz 1964). These behaviors are not assigned by the organization and thus, are voluntary in nature. Employees are not punished for not performing these acts and neither are they rewarded for doing it. Nevertheless, these behaviors are equally important because they allow for the smooth internal operations of the organization which enables it to adapt to the changing external environments. Acts and gestures of altruism, cooperation, goodwill, courtesy, sportsmanship, and other instances help reduce the friction encountered in work situations and under many unforeseen circumstances. Such behaviors reflect Van Scotter's (2000) conceptualization of contextual performance. To sum up, 
viewing job performance that is comprised of two dimensions is in tandem with those of other scholars (for instance, Campbell 1990; Conway 1999). In the customer-organization interface, frontline, customer-contact employees are expected to exhibit high levels of both task and contextual performance.

A review of literature illustrated a vast array of determinants of task performance and contextual performance using samples which have been primarily derived from developed countries especially those in the West. The investigations that focused on task performance as the dependent variables include those of Langhorn's (2004), Morgeson, Delaney-Klinger, and Hemingway's (2005), and Williams's (1999). Meanwhile, studies on contextual performance include those by Farh et al. (1990), Konovsky and Pugh (1994), and Yoon and Suh (2003). Generally, the antecedents of either task performance or contextual performance can be grouped under organizational, job/role, and individual-related categories. Organizational-related predictors comprise of organizational justice (Jin and Shu 2004; Konovsky and Pugh 1994; Konovsky and Organ 1996; Niehoff and Moorman 1993), organizational commitment (Chen and Francesco 2003; MacKenzie et al. 1998; Moorman et al. 1993), leadership (Netemeyer et al. 1997; Podsakoff et al. 1996), perceived organizational support (Farh et al. 1990; Kaufman et al. 2001), and trust (Aryee et al. 2002; Konovsky and Pugh 1994). Job/rolerelated factors include job satisfaction
(Batemanand Organ 1983; MacKenzie et al. 1998; Moorman 1993), job scope (Farhetal. 1990; Morgesonet al. 2005), job characteristics and burnout (Bakker et al. 2004), and role stressors (Fried et al. 1998; MacKenzie et al. 1998). Demographic variables (Pelled et al. 2000; Tang and Ibrahim 1998; Van Emmerik and Sanders 2004), personality traits (Bott et al. 2003; Williams and Sanchez 1998), and emotional intelligence (Carmeli 2003; Langhorn 2004) constitute the individual-related predictors. Research on the topic of job performance using Malaysian subjects has received little empirical attention. The few studies identified have exclusively concentrated on one particular type of job performance, that is, extra-role citizenship behavior (Hemdi et al. 2007; Ishak et al. 2003; Nasurdin and Ramayah 2003). Despite the extensive literature, except for the work by MacKenzie et al. (1998), no other studies have examined the predictors of both forms of performance (task performance and contextual performance) simultaneously. Hence, testing a bidimensional model of job performance using a sample of employees in Malaysia would be helpful in addressing the under-representation of samples from developing countries in the East.

Among the numerous antecedents of individual job performance, fairness perceptions have been regarded as important factors that affect employees' actions and reactions at the workplace (Masterson et al. 2000; Podsakoff et al. 2000). Research into organizational justice has shown that it 
is comprised of two major components: distributive justice and procedural justice (Greenberg 1990). Although numerous studies have been conducted between organizational justice (distributive justice and procedural justice) and work attitudes and behaviors (Folger and Konovsky 1989; Konovsky and Pugh 1994; Moorman 1991; Niehoff and Moorman 1993; Tang and Sarsfield-Baldwin 1996; Williams 1999; Kwon 2006), the relative importance of these two dimensions in explaining the variance in the criterion variables has yet to be clearly demonstrated. Hence, the goal of the present investigation is to examine the influence of organizational justice (distributive justice and procedural justice) on both forms of job performance (task performance and contextual performance) among customer-contact employees in Malaysia.

\section{Review of Literature}

\section{Job Performance}

The meaning of job performance in the field of organizational behavior has changed over the last few decades. There has been a growing realization that job performance is not a unitary construct. In fact, researches have shifted from a focus on fixed tasks associated with the jobs to encompass a broader perspective in a dynamic organizational context (Ilgen and Hollenbeck 1991). Traditionally, performance was evaluated in terms of the proficiency with which an individual carried out the tasks that were prescribed in his or her role descriptions (Griffin et al. 2007). This conceptualization is in tandem with those of earlier scholars (such as Katz 1964; Katz and Kahn 1978). According to these authors, for an organization to function, its members must be able to exhibit dependable role performance, i.e. meet and preferably exceed certain minimal standards. Such role-prescribed work behaviors reflect task performance. According to Motowidlo and Van Scotter (1994), task performance comprises two types of behaviors. The first type consists of activities which directly transform raw materials into the goods and services which the organization produces. The second type comprises of activities that service and maintains the technical core. In other words, when employees use technical skills and knowledge to produce goods or services through the organization's core technical processes, or when they accomplish specialized tasks that support these core functions, they are engaging in task performance (Van Scotter 2000).

The increasing interdependence and uncertainty associated with work and organizations have challenged the traditional views of individual job performance (Ilgen and Pulakos 1999). Although early approaches to job performance have highlighted the need for organizational members to innovatively and spontaneously go beyond prescribed roles to accomplish organizational goals (Katz 1964; Katz and Kahn 1978), the full range of be- 
Nasurdin \& Khuan-OrganizationalJustice as an Antecedent ofJob Performance

haviors that contribute to effectiveness when systems are uncertain and interdependent are not adequately emphasized (Murphy and Jackson 1999). Uncertainty in an organizational context occurs when the inputs, processes, or outputs of work systems lack predictability (Wall et al. 2002). According to Burns and Stalker (1961), the existence of uncertainty in the work environment may be attributed to many factors such as increasing competition, changing technology, and evolving customer demands. When the organizational context is more dynamic, it becomes more difficult for task performance alone to be effective. In such situation, there is greater need for role flexibility whereby employees are required to engage in adaptive and proactive behaviors. Hence, new constructs have emerged that encompass an expanded set of duties and responsibilities. One of such constructs relates to contextual performance, which includes a variety of non-job specific behaviors (Borman and Motowidlo 1993). When employees voluntarily help coworkers who are getting behind, act in ways that maintain good working relationships, or put in extra effort to complete assignment on time, they are engaging in contextual performance (Van Scotter 2000). In sum, contextual performance behaviors do not support the technical core itself as much as they support the broader organizational, social and psychological environment in which the technical core must function (Motowidlo 2000).
Therefore, any measure of performance should capture all aspects of behaviors that have value for the organization. Consistent with this principle, dissection of the performance domain into task performance and contextual performance is important. Furthermore, as previously noted by scholars (Bott et al. 2003; MacKenzie et al. 1998; Motowidlo and Van Scotter 1994; Van Emmerik and Sanders 2004), each of the performance dimensions is associated with a different set of antecedents.

\section{Organizational Justice and Job Performance}

Two sources of organizational justice have been frequently cited in the literature: distributive justice and procedural justice (Moorman 1991). Distributive justice refers to the perceived fairness of the amounts of outcomes employees receive (Greenberg 1990). Procedural justice, on the other hand, reflects a person's judgments about the fairness of the process of making outcome allocations decisions (Greenberg 1990). Specifically, procedural justice relates to the extent in which an individual perceives that outcome allocation decisions have been fairly made according to the organization's formal procedures and from the treatments given by the organization's authorities in enacting those procedures (Moorman 1991). Generally, prior researchers (Jin and Shu 2004; Moorman 1991; Niehoff and Moorman 1993; Williams 1999) conclude that both types of justice influence employees' job behaviors. 
Gadjah Mada International Journal of Business, September - December 2007, Vol. 9, No. 3

\section{Distributive Justice and Job Performance}

Distributive justice is defined as the perceived fairness of the amounts of outcomes employees receives (Greenberg 1990). Basically, it reflects how significant rewards (such as compensation) from organized organizational efforts are fairly distributed among employees (Farh et al. 1990; Folger and Konovsky 1989). The positive relationship between distributive justice and performance may be due to the predictions derived from Adam's (1965) equity theory. The theory posits that human motivation is affected by the outcomes people receive for their inputs, compared to the outcomes and inputs of other people (Pierce and Gardner 2002). When employees feel that they are being treated unequally, they will restore equity by altering their behaviors, attitudes, or both such as to be less productive or vice-versa (Greenberg 1990). In other words, unfair distribution of work rewards relative to work inputs creates tension within an individual, which may ultimately results in a reduction in work inputs. Based on Blau's (1964) economic exchange, distributive justice may results in an increased exhibition of in-role task behavior. On the other hand, when employees define their employment relationships as that of a social one, contextual performance may be deemed as an appropriate response to distributive fairness. Findings from past studies in the West have been divided. Some studies (Moorman
1991; Niehoff and Moorman 1993) find that when two types of justice were measured separately, procedural justice predicts citizenship behaviors but not distributive justice. In contrast, Williams (1999) using an experimental design discovers that distributive justiceperceptions are significantlyand positively related to task performance. Given the paucity of research on the justice-performance relationship in Eastern societies, testing a model linking these variables using a sample of Malaysian employees will be able to address this issue. We expect that there will be similarity in the findings on the positive effect of distributive justice on individual performance as discovered by Western scholars. Therefore, this study posits that:

$H_{I}$ : Distributive justice will be positively related to job performance.

$H_{1 a}$ : Distributive justice will be positively related to taskperformance.

$H_{1 b}:$ Distributive justice will be positively related to contextual performance.

\section{Procedural Justice and Job Performance}

Procedural justice is defined as a person's judgments about the fairness of the process of making outcome allocations decisions (Greenberg 1990). Specifically, procedural justice reflects the extent in which an individual perceives that outcome allocation decisions have been fairly made according to the organization's formal procedures 
Nasurdin \& Khuan—OrganizationalJustice as an Antecedent of Job Performance

and from the treatment given by the organization's authorities in enacting those procedures (Moorman 1991). Since process issues are equally important to people whenever allocations are made (Tyler 1987), it is highly likely that procedural justice may have a potent effect on employees' job performance. Organ (1990) opines that perceived procedural fairness alters an employee's relationship with the organization from one of economic exchange to one of social exchange. In social exchange relationships (Blau 1964), when employees are satisfied with the fairness of procedures, they are more likely to reciprocate by engaging in discretionary behaviors that lie outside of their formal role requirements. These extra-role behaviors relate to contextual performance. Besides, procedural justice is comprised of fair procedures, which include actions such as allowing employees a voice in the decision process, and fair treatment, which is comprised of actions such as providing employees with informationjustifying the outcome they receive, are thought to increase the probability that the distribution of outcomes will be fair (Williams 1999). As a result, employees will be more likely to feel satisfied, and subsequently perform their duties as specified in their job descriptions. Some studies (Jin and Shu 2004; Williams 1999) support the positive relationship between procedural justice judgments and task performance. Others also provide empirical evidence for the positive impact of procedural justice on contextual per-
formance(Jinand Shu 2004; Konovsky and Pugh 1994; Konovsky and Organ 1996; Nasurdin and Ramayah 2003). Based on the aforementioned discussion and findings, it appears that employees' experience of procedural justicemay lead to increased performance. Therefore, the following hypothesis is offered:

$\mathrm{H}_{2}$ : Procedural justice will be positively related tojob performance.

$H_{2 a}$ : Procedural justice will be positively related to task performance.

$H_{2 b}:$ Procedural justice will be positively related to contextual performance.

\section{Methodology}

\section{Subjects}

Participants in the study were customer-contact employees working in the northern and central branches of a telecommunication company in Malaysia. The northern region covering the 10 branches in the states of Penang, Perlis, Kedah, and Perak had 107 customer-contact employees. On the other hand, the central region comprising of 14 branches in Kuala Lumpur and Selangor had 160 customer-contact employees. Questionnaires were distributed and subsequently collected from these 267 employees with the help of the northern and central regional managers. Respondents were given two weeks to answer the questionnaires. 
Gadjah Mada International Journal of Business, September - December 2007, Vol. 9, No. 3

\section{Measurement}

The predictor variables in this study are distributive justice and procedural justice. The criterion variables are task performance and contextual performance. Distributive justice was assessed using 3 items adapted from Moorman (1991). Procedural justice was gauged using 6 items adapted from Niehoff and Moorman (1993). Responses to these items were made on a 5 -point scale $(1=$ strongly disagree to $5=$ strongly agree). The criterion variables relate to the two forms of job performance namely task performance and contextual performance. These two variables were assessed via supervisory ratings. Seven items were used to measure task performance adopted from Williams and Anderson (1991). Another eight items were utilized to gauge contextual performance adapted from Hochwarter et al. (2004). Responses to the items were made on a 5 point scale $(1=$ strongly disagree to $5=$ strongly agree).

\section{Method of Analysis}

Since gender, age, race, job tenure, and organizational tenure have been found to be related to job performance (Bott et al. 2003; Chen and Francesco 2003; Jones and Schaubroeck 2004; Hochwarter et al. 2004; Williams et al. 2002), these personal variables were controlled in the statistical analyses. Data was initially factor analyzed using the criteria de- veloped by Igbaria, Iivaria, and Maragahh (1995). All items conform to the original factors. In the present study, the two hypotheses were tested using hierarchical regression following Cohen and Cohen's (1975) recommendation.

\section{Results}

\section{Profile of Respondents}

In all, 136 useable questionnaires were returned and analyzed representing a response rate of 50.94 percent. A total of 34 superiors were involved in assessing the job performance of the participating customer-contact employees. The demographic profile of the sample is shown in Table 1.

From Table 1, of those who completed the survey, $54(39.7 \%)$ were males and $82(60.3 \%)$ were females. In terms of marital status, 86 respondents were married $(63.2 \%)$ and 50 were unmarried (36.8\%). For ethnicity, 80 respondents were Malays (58.8\%), 40 respondents were Chinese (29.4\%), with the remaining 16 respondents (11.7\%) being Indians and others. Regarding education, a majority of the sample (59.5\%) have polytechnic/college certificates and diplomas. The mean age for the sample was 27.32 years $(\mathrm{SD}=3.53$ years). The mean job tenure and organizational tenure were 3.40 years $(\mathrm{SD}=1.89$ years $)$ and 3.75 years $(\mathrm{SD}=1.98$ years) respectively. 
Nasurdin \& Khuan—OrganizationalJustice as an Antecedent of Job Performance

Table 1. Demographic Profile of Sample

\begin{tabular}{|c|c|c|c|c|}
\hline Demographic Variable & \multicolumn{2}{|c|}{ Categories } & Frequency & Percentage $(\%)$ \\
\hline \multirow[t]{2}{*}{ Gender } & \multicolumn{2}{|c|}{ Male } & 54 & 39.7 \\
\hline & \multicolumn{2}{|c|}{ Female } & 82 & 60.3 \\
\hline \multirow[t]{2}{*}{ Marital Status } & \multicolumn{2}{|c|}{ Unmarried } & 50 & 36.8 \\
\hline & \multicolumn{2}{|c|}{ Married } & 86 & 60.3 \\
\hline \multirow[t]{3}{*}{ Ethnicity } & \multicolumn{2}{|c|}{ Malays } & 80 & 58.8 \\
\hline & \multicolumn{2}{|c|}{ Chinese } & 40 & 29.4 \\
\hline & \multicolumn{2}{|c|}{ Indians and others } & 16 & 11.7 \\
\hline \multirow[t]{4}{*}{ Education } & \multicolumn{2}{|c|}{$\begin{array}{l}\text { Secondary School } \\
\text { Certificates }\end{array}$} & 55 & 40.4 \\
\hline & \multicolumn{2}{|c|}{ College Certificates } & 35 & 25.7 \\
\hline & \multicolumn{2}{|c|}{ Diploma } & 46 & 33.8 \\
\hline & & Mean & \multicolumn{2}{|c|}{ Standard Deviation } \\
\hline Age (years) & & 27.32 & \multicolumn{2}{|c|}{3.53} \\
\hline Job Tenure (years) & & 3.40 & \multicolumn{2}{|c|}{1.89} \\
\hline \multicolumn{2}{|c|}{ Organizational Tenure (years) } & 3.75 & \multicolumn{2}{|c|}{1.98} \\
\hline
\end{tabular}

Mean, Standard Deviations, and Correlations of the Study Variables

Descriptive statistics such as mean scores, standard deviations, reliabilities, and intercorrelations of the study variables are presented in Table 2 .

As depicted in Table 2, on the average, the levels of procedural justiceand distributive justice were judged to be within the moderate to slightly high range. On further scrutiny, re- spondents in this study perceived the level of distributive justice (mean= 4.13, $\mathrm{SD}=1.02$ ) to be higher than that of procedural justice (mean $=3.72, \mathrm{SD}=$ 0.89 ). The mean values for task performance and contextual performance were $3.80(\mathrm{SD}=1.03)$ and $3.88(\mathrm{SD}=$ $0.68)$ respectively. On average, the levels of task performance and contextual performance exhibited by the sample were relatively moderate.

The reliability coefficients for the study variables were above 0.9 which concur with Nunnally's (1978) mini- 
Gadjah Mada International Journal of Business, September - December 2007, Vol. 9, No. 3

mum required level of 0.70 . These high alpha values indicate that the measurements used were reliable. In terms of the correlation values, dis- tributive justice had significant and positive associations with task performance $(r=0.514, p<.01)$ and procedural justice had a significant and posi-

Table 2. Descriptive Statistics, Correlations, and Reliabilities of the Study Variables

\begin{tabular}{|c|c|c|c|c|c|c|}
\hline Variable & Mean & SD & DJ & PJ & $\mathbf{T P}$ & $\mathbf{C P}$ \\
\hline DJ & 4.13 & 1.02 & $(0.94)$ & & & \\
\hline PJ & 3.72 & 0.89 & -0.136 & $(0.92)$ & & \\
\hline $\mathrm{TP}$ & 3.80 & 1.03 & $0.514 * *$ & 0.022 & $(0.95)$ & \\
\hline $\mathrm{CP}$ & 3.88 & 0.68 & -0.052 & $0.375 * *$ & $0.517 * *$ & (0.94) \\
\hline
\end{tabular}

$* * \mathrm{p}<0.01, * \mathrm{p}<0.05$

Note: Values in parentheses on the diagonal indicate reliability coefficients; DJ denotes Distributive Justice, PJ denotes Procedural Justice, TP denotes Task Performance, and $\mathrm{CP}$ denotes Contextual Performance.

Table 3. Results of Regression Analysis: Impact of DJ and PJ on TP

Independent Variables

Control Variables

Age

Job Tenure

Organizational Tenure

Gender $($ Male $=1$, Female $=0$ )

Race 1 (Malay $=1$, Others $=0$ )

Race 2 (Chinese $=1$, Others $=0)$

Model Variables

Distributive Justice

Procedural Justice

$\mathrm{R}^{2}$

Adj. $R^{2}$

$\mathrm{R}^{2}$ - Change

F-Change

${ }^{* *} \mathrm{p}<0.01,{ }^{*} \mathrm{p}<0.05$
Task Performance (TP)

Std Beta (Model 1)

Std Beta(Model 2)

$\begin{array}{rr}0.082 & 0.014 \\ 0.099 & 0.133 \\ -0.237 & -0.219 \\ 0.163 & 0.078 \\ 0.135 & 0.149 \\ 0.079 & 0.100\end{array}$

0.082

0.014

$-0.219$

0.078

0.100
$0.513 * *$

0.083

0.063

0.309

0.019

0.265

0.063

0.246

1.444

344 
Nasurdin \& Khuan-OrganizationalJustice as an Antecedent ofJob Performance

tive association with contextual performance $(r=0.375, p<.01)$. Besides, the correlation coefficient between task performance and contextual performance was significant and positive $(r=0.517, p<.01)$. Other correlations were found to be insignificant.

\section{Hypotheses Testing}

The two dimensions of organizational justice (distributive justice and procedural justice) were regressed on to the two dimensions of performance (task performance and contextual performance) separately. Table 3 reports the results of regressing distributive justice(DJ) and procedural justice (PJ) on task performance (TP).
As reflected in Table 3, control variables were able to explain 6.3 percent of the variance in task performance $\left(R^{2}=0.063\right)$. None of the control variables was found to be related to task performance. The F-change (1.444) was also insignificant. When the two model variables comprising of distributive justice and procedural justice were added into the regression equation, the additional variance explained was 24.6 percent $\left(\mathrm{R}^{2}\right.$-Change $=$ 0.246 , F-change $=22.603, p<.01)$. In the second model, distributive justice $(\hat{\mathrm{a}}=0.513, p<.01)$ alone had a significant and positive effect on task performance. Procedural justice, on the other hand, had no effect on task perfor-

Table 4. Results of Regression Analysis: Impact of DJ and PJ on CP

\begin{tabular}{|c|c|c|}
\hline \multirow[t]{2}{*}{ Independent Variables } & \multicolumn{2}{|c|}{ Contextual Performance (CP) } \\
\hline & Std Beta (Model 1) & Std Beta(Model 2) \\
\hline Control Variables & & \\
\hline Age & -0.177 & -0.192 \\
\hline Job Tenure & 0.037 & 0.009 \\
\hline Organizational Tenure & -0.007 & 0.001 \\
\hline Gender $($ Male $=1$, Female $=0)$ & 0.042 & 0.013 \\
\hline Race 1 (Malay=1,Others $=0)$ & 0.103 & 0.080 \\
\hline Race $2($ Chinese $=1$, Other $=0)$ & 0.146 & 0.102 \\
\hline Model Variables & & \\
\hline Distributive Justice & & 0.020 \\
\hline Procedural Justice & & $0.385 * *$ \\
\hline $\mathrm{R}^{2}$ & 0.034 & 0.178 \\
\hline Adj. $R^{2}$ & -0.010 & 0.127 \\
\hline $\mathrm{R}^{2}$-Change & 0.034 & 0.144 \\
\hline F-Change & 0.768 & $11.114 * *$ \\
\hline
\end{tabular}

$* * \mathrm{p}<0.01, * \mathrm{p}<0.05$ 
mance. This finding provided support for $H_{1 a}$ but not $H_{2 a}$.

Table 4 displays the results of regressing distributive justice (DJ) and procedural justice $(\mathrm{PJ})$ on contextual performance. Results in Table show that control variables in the combination were able to explain 3.4 percent of the variance in contextual performance $\left(\mathrm{R}^{2}=0.034\right)$. None of them was significantly related to contextual performance. The F-change $(0.768)$ was also insignificant. When the two model variables were added into the regression equation, the additional variance explained was 14.4 percent $\left(\mathrm{R}^{2}\right.$ Change $=0.144, \mathrm{~F}$-change $=11.114, p$ $<.01)$. In the second model, only procedural justice $(\hat{\mathrm{a}}=0.385, p<.01)$ was found to have a significant and positive effect on contextual performance. Distributive justice, on the other hand, had no effect on contextual performance. This finding provided support for $H_{2 b}$ but not $H_{l b}$

\section{Discussion, Implication, and Limitations}

The objective of the current study is to examine whether organizational justice dimensions (distributive justice and procedural justice) have positive effects on job performance. The statistical results indicated that the two organizational justice dimensions have separate effects on the two forms of performance. In this study, only distributive justice and task performance is found to be positively related. This finding supports those of Williams's
(1999). When employees define their employment relationships as that of an economic exchange (Blau 1964), they are likely to fulfill their formal employment contract by engaging in inrole behaviors (task performance). In line with the arguments put forth by past scholars (Moorman 1991; Niehoff and Moorman 1993), judgments about the existence of fairness of the ends achieved will foster a state of equity, creating feelings of satisfaction, and resulting in the display of functional behaviors aimed at fulfilling the formal contract of employment. Besides, the respondents in this study were bluecollar, customer-contact Malaysian employees, whose nature of tasks suggest the primacy of productivity goal. According to Meindl (1989), the equity rule is preferred when the task goal relates to productivity. Thus, perceptions of fairness in the reward allocations received may well be more salient as a commodity for economic exchange. In other words, when these workers judged their rewards to be equitable, they are likely to reciprocate by engaging in role-prescribed behaviors.

Procedural justice, however, failed to have any effect on task performance. One probable explanation could be due to the position held by the respondents. In a service setting, customercontact employees may not be in a position to judge the prevalence of procedural fairness. The need to handle customers' queries and problems on an on-going basis would not have enabled them to have the time to retrieve 
information concerning the processes and procedures used in determining their allocation outcomes.

In contrast, procedural justice alone was found to have a significant and positive effect on contextual performance. This finding is consistent with those of past scholars (Jin and Shu, 2004; Konovsky and Pugh 1994; Konovsky and Organ 1996; Nasurdin and Ramayah 2003; Niehoff and Moorman 1993). When employees define their employment relationships as that of social exchange (Blau 1964), they are likely to reciprocate by engaging in discretionary, extra-role behaviors. In tandem with the group-value model (Lind and Tyler 1988), the use of fair procedures and processes help communicate the fact that the employee is a valued member of the group. Such impressions may motivate the employee to behave in a manner that will ensure the welfare of the group. Contextual performance is an example of such behaviors. Besides, people from collectivistic cultures are more concerned for interpersonal harmony and group solidarity (Leung 1988). Hence, they are more inclined to place higher importance on the process of making outcome allocation decisions especially the interpersonal facets of proceduraljustice(Greenberg 2001). Since Malaysia is more of a collectivistic society (Hofstede 1991), perceived procedural fairness may well serve as a key commodity for social exchange. In other words, when these workers judged the process of determining their rewards to be equitable, they are likely to reciprocate by engaging in extrarole contextual behaviors.

On the other hand, distributive justice failed to have any effect on contextual performance. One possible reason may be related to the sample itself. A majority of the Malaysian customer-contact employees surveyed were women $(60.3 \%)$ and married (63.2\%). In countries of the East such as Malaysia, as noted by Mansor (1994), married women are expected to place more attention towards family matters than their jobs or careers. This is in line with the traditional values associated with women as homemakers. According to Gutek, Searle, and Klepa (1991), women are expected to provide a stable home situation rather than financial security. Hence, even though these female workers may judge the outcomes that they have received as fair, they may not be able to spend their time and effort in reciprocating their employers by performing beyond their in-role job requirements.

The strongest implication of this study is that fairness is an important motivator of job performance at the workplace. In order to enhance employees' task performance, managers as representatives of the employing organization should ensure that the outcomes employees received are fair. A key aspect to consider is to reward workers based on objective criteria and merit. Similarly, managers who wish to see an improvement in the contextual performance of their employees must treat them fairly and make use of fair procedures when making 
Gadjah Mada International Journal of Business, September - December 2007, Vol. 9, No. 3

outcomes allocation decisions. Among others, managers need to apply rules fairly and consistently, treat employees with respect and dignity, make job decisions in an unbiased manner, collect accurate and complete information before making job decisions, and show sensitivity towards employees' personal needs.

Finally, the reader is cautioned to recognize the limitations of this study. First, all participants were customercontact employees within the telecommunication industry which may be associated with certain unique features. Thus, the findings obtained may not be generalized to other samples across different industries. The use of a larger sample from diverse sectors would make it easier to generalize the findings. Second, both forms of justice (procedural justice and distributive justice) accounts for about 24.6 percent and 14.4 percent of the variance in task performance and contextual performance respectively. Although these figures are somewhat acceptable, the amount of unexplained variance in job performance is still substantial. This should encourage future researchers to expend their efforts towards identifying other variables that may be able to explain job performance, which include those related to the organization, job, and individual.

\section{References}

Adam, J. S. 1965. Inequity in social exchange. In L. Berkowitz (Ed.), Advances in Experimental Social Psychology 2: 267-299. San Diego, CA: Academic Press.

Aryee, S., P. S. Budhwar, and Z. X. Chen. 2002. Trust as a mediator of the relationship between organizational justice and work outcomes: Test of a social exchange model. Journal of Organizational Behavior 23: 267-280.

Bakker, A. B., E. Demerouti, and W. Verbeke. 2004. Using the job demands-resources model to predict burnout and performance. Human Resource Management 43: 83104.

Bateman, T. S., and D. W. Organ. 1983. Job satisfaction and the good soldier: The relationship between affect and employee "citizenship." Academy of Management Journal 26: 587-595.

Blau, P. M. 1964. Exchange and Power in Social Life. New York: Wiley

Borman, W. C., and S. J. Motowidlo. 1993. Expanding the criterion domain to include elements of contextual performance. In N. Schmitt and W.C.Borman (Eds.), Personnel Selection in Organizations: 71-98. San Francisco, CA: Jossey-Bass.

Borman, W. C., and Motowidlo, S. J. 1997. Task performance and contextual performance: The meaning for personnel selection research. Human Performance 10: 99109. 
Nasurdin \& Khuan—OrganizationalJustice as an Antecedent of Job Performance

Bott, J. P., D. J. Svyantek, S. A. Goodman, and D. S. Bernal. 2003. Expanding the performance domain: Who says nice guys finish last? The International Journal of Organizational Analysis 11: 137-152.

Burns, T., and G. Stalker. 1961. The Management of Innovation. London: Tavistock.

Campbell, J. P. 1990. Modeling the performance prediction problem in industrial and organizational psychology. In M. D. Dunnette and L. M. Hough (Eds.), Handbook of Industrial and Organizational Psychology 1: 687-732. Palo Alto, CA: Consulting Psychologists Press.

Carmeli, A. (2003). The relationship between emotional intelligence and work attitudes, behavior and outcomes: An examination among senior managers. Journal of Managerial Psychology 18: 788-813.

Chen, Z. X., and A. M. Francesco. 2003. The relationship between the three components of commitment and employee performance in china. Journal of Vocational Behavior 62: 490-510.

Cohen, J., and P. Cohen. 1975. Applied Multiple Regression Correlation Analysis for the Behavioral Sciences. Hillsdale, New Jersey: Lawrence Erlbaum Associates.

Conway, J. M. 1999. Distinguishing contextual performance from task performance for managerial jobs. Journal of Applied Psychology 84: 3-13.

Farh, J. L., Podsakoff, P. M., and D. W. Organ. 1990. Accounting for organizational citizenship behavior: Leader fairness and task scope versus satisfaction. Journal of Management 16: 705-721.

Folger, R., and M. A. Konovsky. 1989. Effects of procedural and distributive justice on reactions to pay raise decisions. Academy of Management Journal 32: 115-130.

Fried, Y., H. A. Ben-David, R. B. Tiegs, N. Avital, and U. Yeverechyahu. 1998. The interactive role of role conflict and role ambiguity on job performance. Journal of Occupational and Organizational Psychology 71 (1): 19-27.

George, J. M., and A. P. Brief. 1992. Feeling good-doing good: A conceptual analysis of the mood at work-organizational spontaneity relationship. Psychological Bulletin 112: 310-329.

Greenberg, J. 1990. Organizational justice: Yesterday, today and tomorrow. Journal of Management 16: 399-432.

Greenberg, J. 2001. Studying organizational justice cross-culturally: Fundamental challenges. The International Journal of Conflict Management 12 (4): 365-375.

Griffin, M.A., A. Neal, and S. K. Parker. 2007. A new model of work role performance: Positive behavior in uncertain and interdependent contexts. Academy of Management Journal 50 (2): 327-347.

Gutek, B. A., S. Searle, and L. Klepa. 1991. Rational versus gender role explanations for work-family conflict. Journal of Applied Psychology 76: 56-568.

Hemdi, M. A., A. M. Nasurdin, and M. A. Hamid. 2007. Human resource management practices and organizational citizenship behavior: The mediational role of job satisfaction. The $7^{\text {th }}$ Asian Academy of Management Conference Proceedings 1:367377. 
Hochwarter, W. A., C. Kiewitz, M. J. Gundlach, and J. Stoner. 2004. The impact of vocational and social efficacy on job performance and career satisfaction. Journal of Leadership and Organizational Studies 10: 27-40.

Hofstede, G. 1991. Management in a multicultural society. Malaysian Management Review 16 (1): 3-12.

Igbaria, M., J. Iivari, and H. Maragahh. 1995. Why do individuals use computer technology? A Finnish case study. Information and Management 5: 227-238.

Ilgen, D. R., and J. R. Hollenbeck. 1991. The structure of work: Job design and roles. In M. D. Dunnette and L. M. Hough (Eds.), Handbook of Industrial and Organizational Psychology ( $2^{\text {nd }}$ ed.: 165-207). Palo Alto, CA: Consulting Psychologists Press.

Ilgen, D. R., and E. D. Pulakos. 1999. Employee performance in today's organizations. In D. R. Ilgen and E. D. Pulakos (Eds.), The Changing Nature of Performance: Implications for Staffing, Motivation, and Development: 21-55. San Francisco, CA: Jossey-Bass.

Ishak, N. A., M. A. Ansari, and Z. A. Ahmad. 2003. Leader-member exchange and organizational citizenship behavior: The mediating impact of self-esteem. The Fifth Asian Academy of Management Conference Proceedings 2: 493-503.

Jin, F. U., and Shu, H. C. 2004. Compensation structure, perceived equity and individual performance of RandD professionals. Journal of American Academy of Business 4: 401-405.

Jones, J. R., and J. Schaubroeck. 2004. Mediators of the relationship between race and organizational citizenship behavior. Journal of Managerial Issues 16: 505-527.

Katz, D. 1964. The motivational basis of organizational behavior. Behavioral Science 9: 131-133.

Katz, D., and R. L. Kahn. 1978. The Social Psychology of Organizations. Wiley: New York.

Kaufman, J.D., C. L. Stamper, and P. E. Tesluk. 2001. Do supportive organizations make for good corporate citizens? Journal of Managerial Issues 13: 436-449.

Konovsky, M. A., and D. W. Organ. 1996. Dispositional and contextual determinants of organizational citizenship behavior. Journal of Organizational Behavior 17: 253266.

Konovsky, M. A., and S. D. Pugh. 1994. Citizenship and social exchange. Academy of Management Journal 37: 656-669.

Kwon, J-W. 2006. Distributive and procedural justice as predictors for organizational outcomes in Korea and Malaysia: An integrative model. The Business Review 5 (1): 253-257.

Langhorn, S. 2004. How emotional intelligence can improve management performance. International Journal of Contemporary Hospitality Management 16: 220-230.

Leung, K. 1988. Theoretical advances in justice behavior: Some cross-cultural inputs. In Bond M.H. (Ed.), The Cross-Cultural Challenge in Social Psychology: 218-229. Newbury Park, CA: Sage. 
Nasurdin \& Khuan—OrganizationalJustice as an Antecedent of Job Performance

Lind, E. A., and T. R. Tyler. 1988. The Social Psychology of Procedural Justice. New York, MA: Plenum.

MacKenzie, S. B., P. M. Podsakoff, and M. Ahearne. 1998. Some possible antecedents and consequences of in-role and extra-role salesperson performance. Journal of Marketing 62: 82-98.

Mansor, N. 1994. Women managers in Malaysia: Their mobility and challenges. In N. J. Adler and D. N. Izraeli (Eds.), Women Managers in a Global Economy: 101-113. Cambridge, MA: Basil Blackwell Ltd.

Masterson, S. S., K. Lewis, B. M. Goldman, and M. S. Taylor. 2000. Integrating justice and social exchange: The differing effects of fair procedures and treatment on work relationships. Academy of Management Journal 43 (4): 738-748.

Meindl, J. R. 1989. Managing to be fair: An exploration of values, motives and leadership. Administrative Science Quarterly 34: 252-276.

Moorman, R. H. 1991. Relationship between organizational justice and organizational citizenship behaviors: Do fairness perceptions influence employee citizenship? Journal of Applied Psychology 76: 845-855.

Moorman, R. H. 1993. The influence of cognitive and affective based job satisfaction measures on the relationship between satisfaction and organizational citizenship behavior. Human Relations New York 46: 759-776.

Moorman, R. H., B. P. Niehoff, and D. W. Organ. 1993. Treating employees fairly and organizational citizenship behavior: sorting the effects of job satisfaction, organizational commitment, and procedural justice. Employee Responsibilities and Rights Journal 6: 209-223.

Morgeson, F. P., K. Delaney-Klinger, and M. A. Hemingway. 2005. The importance of job autonomy, cognitive ability, and job-related skill for predicting role breadth and job performance. Journal of Applied Psychology 90: 399-406.

Motowidlo, S. J. 2000. Some basic issues related to contextual performance and organizational citizenship behavior in human resource management. Human Resource Management Review 10: 115-126.

Motowidlo, S. J., and J. R. Van Scotter. 1994. Evidence that task performance should be distinguished from contextual performance. Journal of Applied Psychology 79: 475480.

Murphy, P.R., and S. E. Jackson. 1999. Managing work-role performance: Challenges for $21^{\text {st }}$ century organizations and employees. In D. R. Ilgen and E. D. Pulakos (Eds.), The Changing Nature of Performance: Implications for Staffing, Motivation, and Development: 325-365. San Francisco, CA: Jossey-Bass.

Nasurdin, A. M., and T. Ramayah. 2003. The linkage between procedural justice, perceived organizational support, and extra-role citizenship behavior. The Fifth Asian Academy of Management Conference Proceedings 1: 220-228.

Netemeyer, R. G., J. S. Boles, D. O. McKee, and R. McMurrian. 1997. An investigation into the antecedents of organizational citizenship behaviors in a personal selling context. Journal of Marketing 61 (3): 85-98. 
Gadjah Mada International Journal of Business, September - December 2007, Vol. 9, No. 3

Niehoff, B. P., and R. H. Moorman. 1993. Justice as a mediator of the relationship between methods of monitoring and organizational citizenship behavior. Academy of Management Journal 36 (3): 527-556.

Nunnally, J. C. 1978. Psychometric theory (2 $2^{\text {nd }}$ ed.). New York: McGraw-Hill.

Organ, D.W. 1990. The motivational basis of organizational citizenship behavior. In B. M. Staw and Cummings L. L. (Eds.), Research in Organizational Behavior 12: 4372. Greenwich, CT : JAI Press.

Pelled, L. H., T. G. Cummings, and M. A. Kizilos. 2000. The influence of organizational demography on customer oriented prosocial behavior: An exploratory investigation. Journal of Business Research 47: 209-216.

Pierce, J. L., and D. G. Gardner. 2002. Management and Organizational Behavior: An Integrated Perspective. Cincinnati, Ohio: South-Western.

Podsakoff, P. M., S. B. MacKenzie, and W. H. Bommer. 1996. Transformational leader behaviors and substitutes for leadership as determinants of employee satisfaction, commitment, trust, and organizational citizenship behaviors. Journal of Management 22: 259-298.

Podsakoff, P. M., S. B. MacKenzie, J. B. Paine, and D. G. Bachrach. 2000. Oraganizational citizenship behaviors: A critical review of the theoretical and empirical literature and suggestions for future research. Journal of Management 26: 513-563.

Tang, T. L-P., and A. H. S. Ibrahim. 1998. Antecedents of organizational citizenship behavior revisited: Public personnel in the United States and in the Middle East. Public Personnel 27: 529-550.

Tang, T. L-P., and L. J. Sarsfield-Baldwin. 1996. Distributive and procedural justice as related to satisfaction and commitment. S.A.M.Advanced Management Journal 61: 25-31.

Tyler, T. R. 1987. Conditions leading to value-expressive effects on judgments of procedural justice: A test of four models. Journal of Personality and Social Psychology 52: 333-344.

Van Emmerik, H., and K. Sanders. 2004. Social embeddedness and job performance of tenured and non-tenured professionals. Human Resource Management Journal 14: 40-54.

Van Scotter, J. R. 2000. Relationships of task performance and contextual performance with turnover, job satisfaction, and affective commitment. Human Resource Management Review 10: 79-95.

Wall, T. D., J. L. Cordery, and C. W. Clegg. 2002. Empowerment, performance, and operational uncertainty. Applied Psychology: An International Review 51 (1): 146169.

Wang, Y., H-P. Lo, and Y. V. Hui. 2003. The antecedents of service quality and product quality and their influences on bank reputation: Evidence from the banking industry in China. Managing Service Quality 13: 72-83.

Williams, S. 1999. The effects of distributive and procedural justice on performance. The Journal of Psychology 133: 183-193. 
Nasurdin \& Khuan—OrganizationalJustice as an Antecedent of Job Performance

Williams, L. J., and S. E. Anderson. 1991. Job satisfaction and organizational commitment as predictors of organizational citizenship and in-role behaviors. Journal of Management 17: 601-617.

Williams, S., R. Pitre, and M. Zainuba. 2002. Justice and organizational citizenship behavior intentions: Fair rewards versus fair treatment. The Journal of Social Psychology 142: 33-44.

Williams, M., and J. I. Sanchez. 1998. Customer service-oriented behavior: Person and situational antecedents. Journal of Quality Management 3: 101-116.

Yoon, M. H., and J. Suh. 2003. Organizational citizenship behaviors and service quality as external effectiveness of contact employees. Journal of Business Research 56: 597-611. 